STUDIA PRAWNO-EKONOMICZNE, t. CIV, 2017

PL ISSN 0081-6841; e-ISSN 2450-8179 $\quad$ s. 315-328

DOI: 10.26485/SPE/2017/104/18

\title{
Magdalena ROSIŃSKA-BUKOWSKA*
}

\section{KORPORACJE TRANSNARODOWE WOBEC WYZWAŃ XXI WIEKU}

\begin{abstract}
(Streszczenie)
Celem artykułu jest próba wskazania głównych kierunków zmian w korporacjach transnarodowych (KTN) w wyniku przemian zachodzących w gospodarce światowej, w efekcie przechodzenia kolejnych fal globalizacji. Przedstawiono proces integracji systemów korporacyjnych jako mechanizm dostosowawczy, będący odpowiedzią KTN na coraz to nowe wyzwania. Efektem zmian jest kreacja globalnych sieci biznesowych (GSB) i pojawienie się KTN-orchestrators. KTN-orchestrators GSB to najpotężniejsze KTN, które uzyskały ten status, budując swoje modele rozwojowe na ideach koherencji, zrównoważonego zarządzania, orkiestracji, regulacji. Wykorzystując metodologię teorii ugruntowanej, ustalono, że filarami strategii KTN-orchestrators są: sieciowość, kooperencja, glokalność, wielopłaszczyznowość.

Artykuł składa się z trzech części. Pierwsza przedstawia ewolucję KTN postrzeganą jako konsekwencja implementacji wyzwań stawianych przez gospodarkę światową. Podkreślono, że kolejne etapy globalizacji wymuszały systematyczne zmiany w modelach biznesowych korporacji. Zauważono, że dostosowania strategiczne układają się w pewien charakterystyczny schemat. Metoda poprawy konkurencyjności podmiotów uczestniczących przypomina realizację klasycznej koncepcji integracji gospodarczej - skonstruowano model procesu integracji biznesowej. Druga część opracowania stanowi próbę wyjaśnienia istoty modelu KTN-orchestrators GSB oraz zmian w modelach zarządzania tych organizacji, które aby sprostać nowym wyzwaniom, wypracowały adekwatne filary modeli rozwojowych. Zwrócono uwagę, że ten nowy typ podmiotów ze względu na swój charakter powinien być traktowany inaczej niż tradycyjne, monolityczne KTN. W ostatniej części artykułu w celu egzemplifikacji zbieżności priorytetów strategicznych KTN-orchestrators ze wskazanymi w oparciu o metodologię Grounded Theory Method filarami przedstawiono studium przypadku dla sektora motoryzacyjnego (Toyota, Ford, VW) - stanowiące element całości przeprowadzonego badania na grupie $250 \mathrm{KTN}$ notowanych w Top 100 non-financial TNCs World Investment Report 1991-2013.
\end{abstract}

Słowa kluczowe: korporacje transnarodowe; KTN; orkiestracja; globalizacja; sieci biznesowe Klasyfikacja JEL: F23, D85, L62, M14

* Dr hab., prof. nadzw. UŁ, Uniwersytet Łódzki, Wydział Ekonomiczno-Socjologiczny, Katedra Biznesu i Handlu Międzynarodowego; e-mail: magdalena_rosinska@uni.lodz.pl 


\section{Wstęp}

Istotę korporacji transnarodowych $(\mathrm{KTN})$ stanowi stałe pomnażanie zasobów wiedzy dzięki wewnętrznie spójnej, choć zróżnicowanej strukturze. Celem artykułu jest wskazanie kluczowych zmian zachodzących w strukturach organizacyjno-zarządczych KTN w efekcie dostosowań do wyzwań stawianych im przez ewoluującą gospodarkę światową. Podkreślono, że kolejne fale globalizacji przyniosły na tyle odmienne wymogi budowania konkurencyjności na rynku międzynarodowym, że dokonywanie przez KTN rewizji zapisów strategii i systematycznej przebudowy modeli organizacyjno-zarządczych było koniecznością. Efekt to pogłębianie procesu kreacji globalnych sieci biznesowych (GSB) i pojawienie się KTN-orchestrators ${ }^{1}$. Uzasadnieniem znaczenia podjętego tematu jest fakt, że budowanie GSB wokół KTN-orchestrators oznacza oligopolizację poszczególnych sektorów, a zatem jest istotne dla innych przedsiębiorstw, organizacji pozarządowych, władz krajowych i lokalnych. Założeniem badania jest, że KTN-orchestrators GSB to te KTN, które najlepiej implementują w swoich strategiach idee koherencji ${ }^{2}$, kooperencji ${ }^{3}$ i orkiestracji ${ }^{4}$. Pytania badawcze to: czy można wykazać, że KTN wypracowały model dostosowań do pojawiających się wyzwań - tzn. postępowały według pewnego schematu, gdyż odpowiadały na kolejne wymogi? Czy możliwe jest wykazanie, że w konsekwencji osiagnięcia fazy GSB strategie KTN-orchestrators bazują na identycznych filarach? Za wzo-

Istotę postawy orchestratora wyjaśnia paradygmat H.H. Stevensona. T.E. Brown, P. Davidsson, J. Wiklund, An Operationalization of Stevenson's Conceptualization of Entrepreneurship as Opportunity - based Firm Behavior, Strategic Management Journal 2001/22, s. 953-968. Pojęcie orchestrator upowszechnili J. Hagel, J.S. Brown, The Only Sustainable Edge: Why Business Strategy Depends on Productive Friction and Dynamic Specialization, Harvard Business School Press, Boston 2005.

2 Koherencja pozwala na godzenie (co nie oznacza niwelowania) różnorodności poprzez uwypuklanie wspólnych wartości i na tej bazie wypracowywanie skutecznych mechanizmów i dobrych praktyk służących kreowaniu wartości dodanej. V.K. Fung, W.K. Fung, Y. Wind (Jr.), Konkurowanie w płaskim świecie, Wydawnictwa Akademickie i Profesjonalne, Warszawa 2008, s. 40-42; B. De Wit, R. Meyer, Synteza strategii, PWE, Warszawa 2007, s. 242-244.

3 Kooperencja to układ strumieni jednoczesnych i współzależnych relacji konkurencji i kooperacji między podmiotami, które zachowują swoją odrębność organizacyjną. J. Cygler, Kooperencja przedsiębiorstw, Wydawnictwo SGH, Warszawa 2009, s. 19-64.

4 Orkiestracja - mechanizm regulacyjny łańcucha wartości, wykorzystujący zróżnicowane zasoby członków wielopoziomowej sieci, którzy niekoniecznie są zespoleni formalnie czy organizacyjnie. T. Pedersen, M. Venzin, T.M. Devinney, L. Tihanyi (red.), Orchestration of the Global Network Organization, Emerald Group Publishing, Howard House, Wagon Lane, Bingley, Advances in International Management 2014/27. 
rzec drogi dostosowań KTN do wymogów zmieniającej się gospodarki światowej przyjęto skonstruowany w oparciu o koncepcję integracji gospodarczej B. Balassy model integracji biznesowej ${ }^{5}$. Filary modeli biznesowych KTN-orchestrators wskazano na podstawie badań strategii wiodących korporacji ${ }^{6}$ - wykorzystując metodologię Grounded Theory Method. Tezą opracowania jest, że odpowiedzią KTN na wyzwania XXI w. jest kreacja GSB wokół KTN-orchestrators, czyli tych korporacji, które przebudowały swoje modele rozwojowe zgodnie z logiką dokonujących się zmian, wypracowując pewne uniwersalne filary strategii.

Artykuł składa się z trzech części. W pierwszej starano się wskazać kluczowe wyzwania kolejnych etapów globalizacji, które determinowały modyfikacje strategii KTN. Zwrócono uwagę na zmiany dotyczące głównych strumieni przepływów i ewoluowanie modelu budowania przewagi na rynku międzynarodowym. Przechodzenie kolejnych etapów integracji biznesowej i kreację GSB uznano za wyraz implementacji tych zmian w strategiach KTN. W drugiej części podjęto próbę wyjaśnienia istoty KTN-orchestrators GSB. W oparciu o metodologię teorii ugruntowanej ustalono, że realizują one wyzwanie utrzymania równowagi między organizacją a dynamicznym otoczeniem zewnętrznym i wewnętrznym, stosując modele organizacyjno-zarządcze bazujące na uniwersalnych filarach strategicznych. Są nimi: glokalność, sieciowość, kooperencja, wielopłaszczyznowość. W ostatniej części zaprezentowano próbę egzemplifikacji zasad oceny spójności filarów strategii KTN-orchestrators GSB - zestawiając zapisy z raportów KTN (Forda, Toyoty i Volkswagena) z ustalonymi w toku badania filarami.

\section{Zmiany w strategiach KTN jako efekt ewolucji gospodarki światowej}

Podstawowym założeniem jest, że determinantą zmian zachodzących w KTN była ewoluująca w rytm globalizacji gospodarka światowa. W efekcie tradycyjne korporacje, bazujące na sile własnego kapitału przekształcały się w złożone struktury półotwarte. Najpotężniejsze z nich, które zbudowały wokół siebie wielopoziomowe sieci, zawierające liczne typy powiązań (własnościowych,

\footnotetext{
W modelu zachowania KTN przyporządkowano wymogom kolejnych etapów procesu integracyjnego. M. Rosińska-Bukowska, Rozwój globalnych sieci biznesowych jako strategia konkurencyjna korporacji transnarodowych, Wydawnictwo Uniwersytetu Łódzkiego, Łódź 2012, s. 179-186.

6 Obiekty badania: ponad $200 \mathrm{KTN}$ z listy Top 100 non-financial TNCs World Investment Report 1991-2013.
} 
strategicznych, kooperacyjnych, w tym niekapitałowych ${ }^{7}$ ) - stały się KTN-orchestrators GSB. Istotą KTN-orchestrators jest zdolność zarządzania globalnym łańcuchem wartości poprzez integrację i koordynację półotwartych systemów, czyli strategia internacjonalizacji sieciowej będąca tzw. niekonwencjonalnym podejściem, uwzględniającym złożony kontekst społeczny ${ }^{8}$. Strategia ta uzewnętrznia się kreacją struktur hybrydowych, łączących różne typy łańcuchów kreowania wartości9: rynkowy, modułowy, relacyjny, zakotwiczony, hierarchiczny. Dlatego do analiz KTN-orchestrators GSB wymagane jest stosowanie metod analizy sieciowej ${ }^{10}$.

Przejście gospodarki światowej przez kolejne fazy globalizacji doprowadziło zatem do wyłonienia KTN-orchestrators GSB w poszczególnych sektorach. Stanowi to wypełnienie wymogów globalizacji korporacyjnej - połączenie paradygmatów KKK (kontrola, konkurencja, kooperacja) ${ }^{11}$ i OLI (własność, lokalizacja, internalizacja $)^{12}$. W tabeli 1 przedstawiono ewoluowanie wyzwań kolejnych etapów globalizacji ${ }^{13} \mathrm{i}$ ich konsekwencje dla strategii KTN.

TABELA 1: Etapy globalizacji a wyzwania dla przedsiębiorstw

\begin{tabular}{|l|l|l|l|}
\hline \multicolumn{1}{|c|}{ Etap globalizacji } & $\begin{array}{l}\text { Główne strumienie } \\
\text { przepływów }\end{array}$ & $\begin{array}{l}\text { Nacisk strategiczny } \\
\text { Paradygmat }\end{array}$ & \multicolumn{1}{|c|}{ Model przewagi } \\
\hline Internacjonalizacja & $\begin{array}{l}\text { Handel } \\
\text { Towary }\end{array}$ & $\begin{array}{l}\text { Umowy bilateralne } \\
\text { Korzyści skali }\end{array}$ & Komparatywna \\
\hline Umiędzynarodowienie & $\begin{array}{l}\text { Inwestycje } \\
\text { Czynniki produkcji }\end{array}$ & $\begin{array}{l}\text { Stabilność udziału } \\
\text { w rynku branżowym }\end{array}$ & $\begin{array}{l}\text { Konkurencyjna } \\
\text { - w danym segmencie }\end{array}$ \\
\hline
\end{tabular}

7 T. Pakulska, M. Poniatowska-Jach, Non-Equity Modes as international business strategy. From Ownership to Control, Lambert Academic Publishing, Saarbrücken 2015.

8 M. Gorynia, B. Jankowska, Teorie internacjonalizacji, Gospodarka Narodowa 2007/10, s. $31-40$.

9 G. Gereffi, J. Humphrey, T. Sturgeon, The governance of global value chains, Review of International Political Economy 2005/12/1.

10 P. Klimas, Structural face of competition, cooperation and coopetition inside business networks, Argumenta Oeconomica 2015/1/34, s. 127-155.

11 A. Sulejewicz, Partnerstwo strategiczne: modelowanie wspótpracy przedsiębiorstw, Monografie i Opracowania 1997/427, Wydawnictwo SGH, Warszawa, s. 192-194.

12 J.H. Dunning, The Eclectic (OLI) Paradigm of International Production: Past, Present and Future, International Journal of the Economics of Business 2001/8/2, s. 173-190.

13 Internacjonalizacja - dominacja nieregularnych „poszukujących” działań eksportowych. Umiędzynarodowienie - budowanie regularnych i trwatych relacji na rynkach zagranicznych jako konieczność rozwojowa. F. Wiedersheim-Paul, H.C. Olson, L.S. Welch, Pre-Export Activity: The First Step in Internationalization, Journal of International Business Studies 1978/9 (1), s. 47-58 oraz A. Blomstermo, D. Deo Sharma, Learning in the Internationalization Process of Firm, Edward Elgar Publishing, Cheltenham Northampton, Massachusetts 2003, s. 262-263. 


\begin{tabular}{|l|l|l|l|}
\hline \multicolumn{1}{|c|}{ Etap globalizacji } & $\begin{array}{l}\text { Główne strumienie } \\
\text { przepływów }\end{array}$ & $\begin{array}{l}\text { Nacisk strategiczny } \\
\text { Paradygmat }\end{array}$ & Model przewagi \\
\hline $\begin{array}{l}\text { Globalizacja } \\
\text { sensu stricto }\end{array}$ & $\begin{array}{l}\text { Transfer wiedzy } \\
\text { Przepływ kapitału }\end{array}$ & $\begin{array}{l}\text { Rozwój struktur } \\
\text { globalnych } \\
\text { Udział w rynku } \\
\text { globalnym }\end{array}$ & $\begin{array}{l}\text { Oligopolistyczna } \\
\text { - udział w rynku } \\
\text { globalnym }\end{array}$ \\
\hline $\begin{array}{l}\text { Globalizacja } \\
\text { korporacyjna }\end{array}$ & $\begin{array}{l}\text { Wewnątrzsieciowe } \\
\text { strumienie } \\
\text { (towary, usługi, } \\
\text { kapitał, wiedza) }\end{array}$ & $\begin{array}{l}\text { OLI (własność, } \\
\text { lokalizacja, } \\
\text { internalizacja) } \\
\text { KKK (kontrola, } \\
\text { konkurencja, } \\
\text { kooperacja) }\end{array}$ & $\begin{array}{l}\text { Kooperencyjna } \\
\text { - zrównoważony } \\
\text { rozwój, } \\
\text { synergia, społeczna } \\
\text { wartość dodana }\end{array}$ \\
\hline
\end{tabular}

Ź r ó d ł o: opracowanie na podstawie: M. Rosińska-Bukowska, Rozwój globalnych sieci biznesowych jako strategia konkurencyjna korporacji transnarodowych, Wydawnictwo Uniwersytetu Łódzkiego, Łódź 2012, s. 40-47.

Przekształcanie wiodących korporacji w KTN-orchestrators GSB i włączanie w struktury sieci dotychczas samodzielnych podmiotów (w tym słabszych KTN) należy traktować jako proces dostosowań uczestników do zmieniających się warunków rynkowych. Etap ten oznacza akceptację idei modelu regulacyjnego, czyli dobrowolnego ograniczania własnej suwerenności na rzecz poprawy efektywności. GSB bazuje na koherencji członków systemu. Analiza procesów pogłębiania zakresu integracji sieci, budowania kolejnych warstw powiązań i tworzenia sprawnego systemu orkiestracji na przykładach najpotężniejszych korporacji wykazała, że idea jest podobna do koncepcji integracji gospodarczej państw. W efekcie stworzono model integracji biznesowej służący uporządkowaniu procesu internacjonalizacji sieciowej z wykorzystaniem powszechnie akceptowalnego wzorca (tabela 2).

TABELA 2: Model integracji biznesowej

\begin{tabular}{|l|l|}
\hline \multicolumn{1}{|c|}{$\begin{array}{c}\text { Model } \\
\text { wzorcowy }\end{array}$} & \multicolumn{1}{c|}{ Model integracji biznesowej - integracja przedsiębiorstw } \\
\hline $\begin{array}{l}\text { Strefa } \\
\text { wolnego handlu }\end{array}$ & $\begin{array}{l}\text { Umowy o współpracy - zróżnicowana oferta; porozumienia w łańcuchu } \\
\text { produkcyjnym (specjalizacja fazowa); niewielka siła indywidualnych } \\
\text { podmiotów skłania do aglomeracji (dystrykty); ekspansja o zasięgu } \\
\text { regionalnym - mały dystans ,psychologiczny”; brak wyraźnego lidera }\end{array}$ \\
\hline Unia celna & $\begin{array}{l}\text { Stała kooperacja i jednolita polityka wobec podmiotów trzecich; joint } \\
\text { venture na bliskich kulturowo i geograficznie rynkach; idea klastra } \\
\text { - geograficzne skupisko wyspecjalizowanych podmiotów; wykorzystanie } \\
\text { warunków lokalnych - endogeniczne cechy ,regionu” - atmosfera } \\
\text { przemysłowa }\end{array}$ \\
\hline
\end{tabular}




\begin{tabular}{|c|l|}
\hline \multicolumn{1}{|c|}{$\begin{array}{c}\text { Model } \\
\text { wzorcowy }\end{array}$} & \multicolumn{1}{c|}{ Model integracji biznesowej - integracja przedsiębiorstw } \\
\hline Wspólny rynek & $\begin{array}{l}\text { Jednolita polityka wewnętrzna: klasy produktów, segmenty rynku; działy } \\
\text { - konsolidacja sfer aktywności i intensyfikacja powiązań - produkcja, } \\
\text { dystrybucja, technologia, kapitał i zasoby ludzkie; } \\
\text { system 4 typów filii (4 swobody) - handel-usługi, produkcja, technologia, } \\
\text { strategiczne }\end{array}$ \\
\hline $\begin{array}{l}\text { Unia } \\
\text { ekonomiczna }\end{array}$ & $\begin{array}{l}\text { Globalna koordynacja sieci - alianse strategiczne, intensyfikacja M\&As } \\
\text { Globalna koordynacja - centra kompetencji sieci (rotacyjne/kompetencyjne } \\
\text { przywództwo) }\end{array}$ \\
\hline Unia walutowa & $\begin{array}{l}\text { Pozycjonowanie produktów w ramach sieci - portfel marek } \\
\text { Możliwa wspólna marka (,waluta”) lub parasol wspólnej marki }\end{array}$ \\
\hline Unia polityczna & $\begin{array}{l}\text { Globalne sieci biznesowe - oligopole o ukształtowanych obszarach } \\
\text { kluczowych kompetencji i globalnych strukturach regulacyjnych; sieci } \\
\text {,zewnętrznie” samodzielnych podmiotów; kooperencja } \\
\text { Przywództwo kompetencyjne; model orkiestracji; strategicznie zorientowany } \\
\text { łańcuch wartości } \\
\text { Społeczna odpowiedzialność }\end{array}$ \\
\hline
\end{tabular}

Ź r ó d ł o: opracowanie na podstawie: M. Rosińska-Bukowska, Najpotężniejsze korporacje współczesnego świata, Wydawnictwo WSSM, Łódź 2011, s. 235-240.

Istotę modelu integracji biznesowej stanowi zaakcentowanie przejścia od modelu bezpośredniego zarządzania zależnymi elementami KTN do modelu kreatywnej orkiestracji wielopoziomowego systemu GSB. Na schemacie 1 przedstawiono koncepcję kreacji GSB, akcentując ewolucję idei kapitalizmu, a także łączenie różnorodnych typów struktur i modeli sieci w toku procesu integracji biznesowej.

Konkludując, KTN, starając się sprostać coraz to nowym wyzwaniom, dokonywały istotnych przewartościowań w swoich strategiach. Przyjęta przez KTN ścieżka zmian jest zbliżona do koncepcji integracji państw. W jego toku najpotężniejsze korporacje przekształciły się w KTN-orchestrators GSB. Ich strategie bazują na koherencji, kooperencji, orkiestracji, czyli zrozumieniu istoty modelu regulacyjnego ${ }^{14} \mathrm{i}$ docenieniu wagi rozwoju zrównoważonego w systemie z udziałem zróżnicowanych interesariuszy.

14 M. Gorynia, B. Jankowska, Klastry a międzynarodowa konkurencyjność i internacjonalizacja przedsiębiorstwa, Difin, Warszawa 2008, s. 23; G. Thomson, J. Frances, R. Levacic, J. Mitchell, Markets, Hierarchies and Networks: The Co-ordination of Social Life, Sage Publications, London 1991, s. 265-276. 
SCHEMAT 1: Idea tworzenia globalnej sieci biznesowej

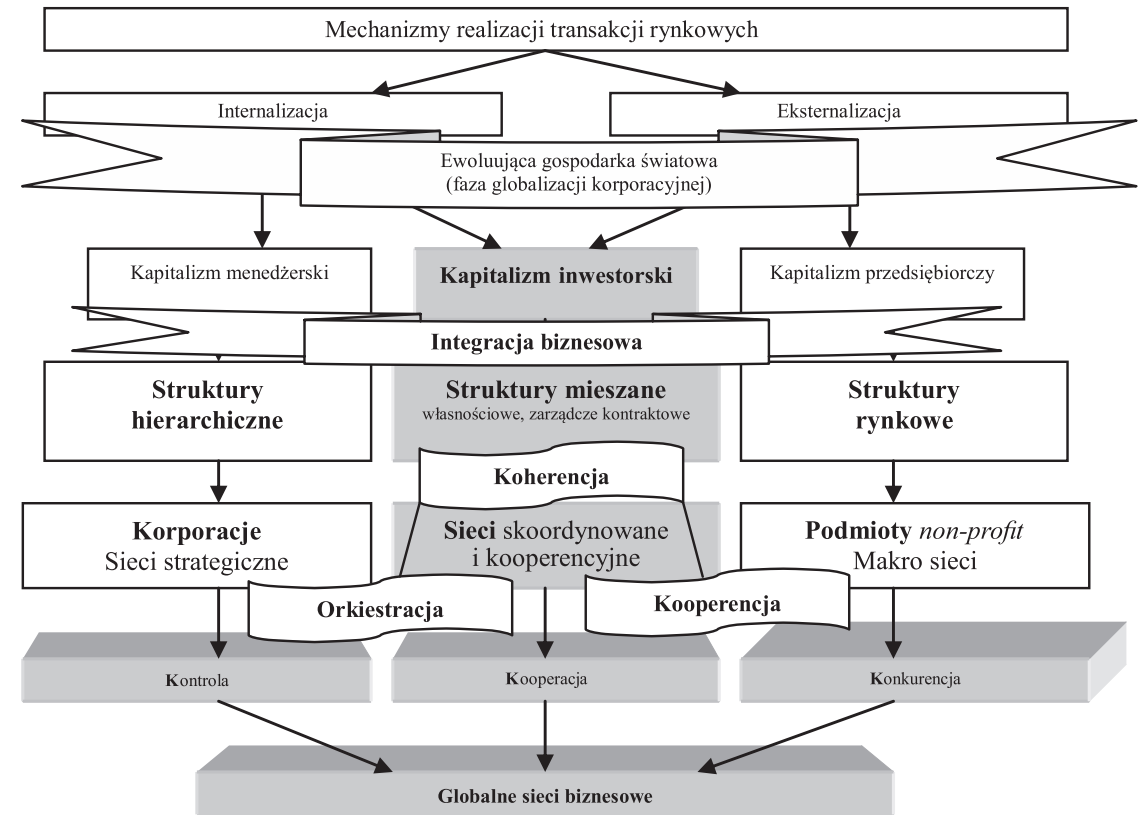

Źródło: opracowanie własne.

\section{Podstawy wskazania KTN-orchestrators GSB i filarów ich strategii}

W celu ustalenia listy potencjalnych KTN-orchestrators odwołano się do koncepcji międzynarodowej konkurencyjności gospodarek ${ }^{15}$, uznawanej za modelową ocenę systemów złożonych. Ustalono, że KTN-orchestrator musi posiadać wielowarstwowy kapitał, wskazujący na możliwość utrzymania stabilnej pozycji na rynku międzynarodowym. Przyjęto, że punktem wyjścia do uznania zdolności danej korporacji do stania się KTN-orchestrator są odpowiednie poziomy aktywów, przychodów, zatrudnienia, wartości rynkowej. Podmiot musi też znaleźć się na liście World's Most Admired Companies sektora, posiadać cenne marki oraz system zakotwiczeń poza krajem macierzystym (M\&As, joint venture, inwestycje w B+R, edukację, ochronę środowiska).

15 M.-J. Radło, Międzynarodowa konkurencyjność gospodarki, w: W. Bieńkowski i in., Czynniki i miary międzynarodowej konkurencyjności gospodarek w kontekście globalizacji - wstępne wyniki badań, Prace i Materiały, nr 284, IGŚ SGH, Warszawa 2008, s. 20-25. 
Na podstawie danych World Investment Report (1990-2014) wykonano zestawienia danych, obliczenia wskaźników, porównania dla ponad $200 \mathrm{KTN}$. Następnie dokonano ich podziału na sektory. W sektorach pogłębiono badanie: oferty, cennych marek, wyznaczania standardów, przejścia etapów integracji biznesowej. Dla KTN spełniających wszystkie wymogi przeprowadzono badania koncepcji strategicznych. Porównano zapisy w ich raportach z raportami organizacji pozarządowych, statystykami lobbingu, ocenami wieloparametrowymi, doniesieniami prasowymi etc. Ustalono, że zapisy dotyczące realizowanej strategii ewoluują i układają się w cztery priorytety. Wykorzystując metodologię teorii ugruntowanej ${ }^{16}$, jako ,uniwersalne” filary rozwoju KTN-orchestrators wskazano: glokalność, sieciowość, kooperencję, wielopłaszczyznowość. Zjawisko występuje niezależnie od sektora. Jego zakres pokrywa się z zakresem zaawansowania procesów integracji biznesowej w poszczególnych sektorach (tabela 3).

TABELA 3: Syntetyczne zestawienie wyników badań - ujęcie sektorowe

\begin{tabular}{|c|c|c|c|c|c|c|c|c|c|c|}
\hline \multicolumn{2}{|c|}{ Badanie dla $252 \mathrm{KTN}$} & $\begin{array}{l}\text { Motor. } \\
(17)\end{array}$ & $\begin{array}{c}\text { Elekr. } \\
(26)\end{array}$ & $\begin{array}{l}\text { Petroch. } \\
(25)\end{array}$ & $\begin{array}{l}\text { Chem. } \\
(30)\end{array}$ & $\begin{array}{c}\text { Telek. } \\
(38)\end{array}$ & $\begin{array}{c}\text { Kons. } \\
(36)\end{array}$ & $\begin{array}{c}\text { Przem. } \\
(40)\end{array}$ & $\begin{array}{l}\text { Użyt. } \\
\text { publ. } \\
(29)\end{array}$ & $\begin{array}{l}\text { Wie- } \\
\text { lobr. } \\
(11)\end{array}$ \\
\hline \multicolumn{2}{|c|}{$\begin{array}{l}\text { integracja biznesowa - osią- } \\
\text { gnięcie etapu GSB (\% ogółu) }\end{array}$} & $\begin{array}{c}10 \\
(59 \%)\end{array}$ & $\begin{array}{c}13 \\
(50 \%)\end{array}$ & $\begin{array}{c}6 \\
(24 \%)\end{array}$ & $\begin{array}{c}11 \\
(37 \%)\end{array}$ & $\begin{array}{c}8 \\
(21 \%)\end{array}$ & $\begin{array}{c}21 \\
(58 \%)\end{array}$ & $\begin{array}{c}15 \\
(37 \%)\end{array}$ & $\begin{array}{c}4 \\
(14 \%)\end{array}$ & $\begin{array}{c}2 \\
(18 \%)\end{array}$ \\
\hline $\begin{array}{l}\text { Zbieżność } \\
\text { priorytetów } \\
\text { rozwojowych } \\
\text { KTN-orche- } \\
\text { strators GSB }\end{array}$ & \begin{tabular}{|l} 
sieciowość \\
kooperencja \\
glokalność \\
wielo- \\
płaszcz.
\end{tabular} & $\begin{array}{l}+++ \\
+++ \\
+++ \\
+++\end{array}$ & $\begin{array}{l}+++ \\
+++ \\
+++ \\
+++\end{array}$ & $\begin{array}{c}++ \\
+++ \\
+++ \\
++\end{array}$ & $\begin{array}{l}+++ \\
+++ \\
+++ \\
+++\end{array}$ & $\begin{array}{c}++ \\
+ \\
++ \\
++\end{array}$ & $\begin{array}{c}+++ \\
++ \\
+++ \\
+++\end{array}$ & $\begin{array}{c}+ \\
++ \\
+++ \\
+++\end{array}$ & $\begin{array}{c}++ \\
+ \\
+++ \\
+\end{array}$ & $\begin{array}{c}+ \\
+ \\
++ \\
+\end{array}$ \\
\hline
\end{tabular}

Znaczenie: + podstawowe, ++ istotne, +++ kluczowe.

Ź r ó d ł o: opracowanie na podstawie wyników badań własnych.

Badanie wykazało, że w sektorach, w których status KTN-orchestrators wśród Top 100 TNC-s osiagnął najwyższy odsetek, zapisy strategii wskazują na pełną zbieżność priorytetów rozwojowych. Ich filary rozwoju można wówczas sprowadzić do idei: sieciowości - sieć wielopoziomowa z powiązaniami własnościowymi, strategicznymi i kooperacyjnymi; kooperencji - zarządzanie na zasadach systemu regulacyjnego, kreacja wartości w wyniku stałych, wewnętrznych interakcji wszystkich podsystemów, wymagająca łączenia konkurencji ze współpracą; glokalności - działania pod stała presją globalnych wyzwań i dostosowań do lokalnych specyfik; wielopłaszczyznowości - wielość typów struktur organizacyjno-zarządczych, strategii marki, dystrybucji, zarządzania zasobami oparta na idei koherencji.

16 M. Götz, B. Jankowska, Zastosowanie metodologii teorii ugruntowanej (GTM) w badaniu koopetycji w klastrach, Problemy Zarządzania 2014/12/3 (47), s. 185-205. 


\section{Spójność filarów rozwoju KTN-orchestrators - case study dla sektora motoryzacyjnego}

W celu egzemplifikacji sposobu oceny zbieżności priorytetów strategicznych KTN-orchestrators ze wskazanymi filarami przywołano przykład dla sektora motoryzacyjnego. Dobór przypadków: Toyoty, Volkswagena oraz Forda był celowy. Przez cały okres analizy (1990-2014) były notowane w World Investment Report. Są klasyfikowane stale w sektorze motoryzacyjnym. Ukształtowały rozpoznawalną ofertę z zastosowaniem zróżnicowanych strategii marki, wyznaczają standardy w branży. Równocześnie pochodzą z różnych obszarów cywilizacyjno-kulturowych, co ma istotne znaczenie dla modelu zarządzania. Analiza wykazała, że ich ścieżki rozwojowe, w tym metody wypełniania kolejnych wymogów modelu integracji Biznesowej, były nieco inne, jednak wszystkie wdrażały strategię internacjonalizacji sieciowej ${ }^{17}$. Konkluzja - spełniają we wszystkich parametrach wymogi KTN-orchestrators. Wizualizację ich strategii na tle wystandaryzowanych filarów przedstawiają schematy $2,3,4$.

SCHEMAT 2: Filary modelu Toyota Motor

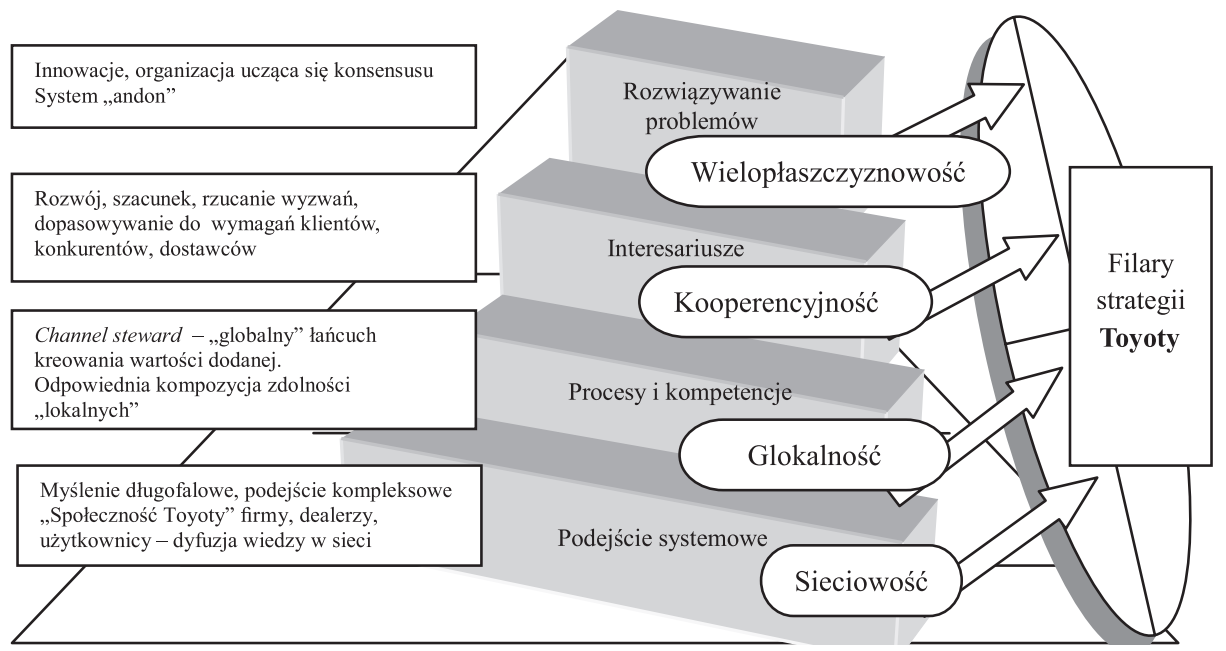

Ź r ó d ł o: opracowanie z wykorzystaniem elementów: J.K. Liker, Droga Toyoty. 14 zasad zarzqdzania wiodacej firmy produkcyjnej świata, Wydawnictwo MT Biznes, Warszawa 2005, s. 21-50 oraz Toyota's DNA 2014.

17 T. Pedersen, M. Venzin, T.M. Devinney, L. Tihanyi (red.), Orchestration of the Global Network Organization, Emerald Group Publishing, Howard House, Wagon Lane, Bingley, Advances in International Management 2014/27. 


\section{SCHEMAT 3: Filary modelu Ford Motor}

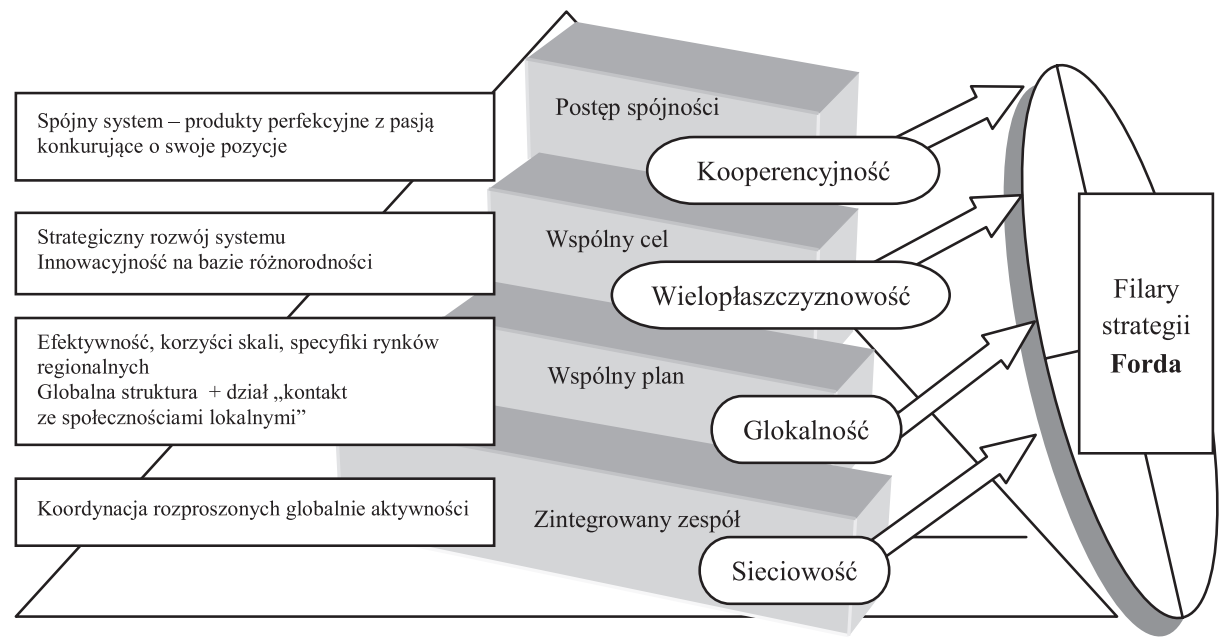

Ź r ó d ł o: opracowanie własne na podstawie: Annual Report Ford Motor Company 2014 oraz 2010.

\section{SCHEMAT 4: Filary modelu Volkswagen}

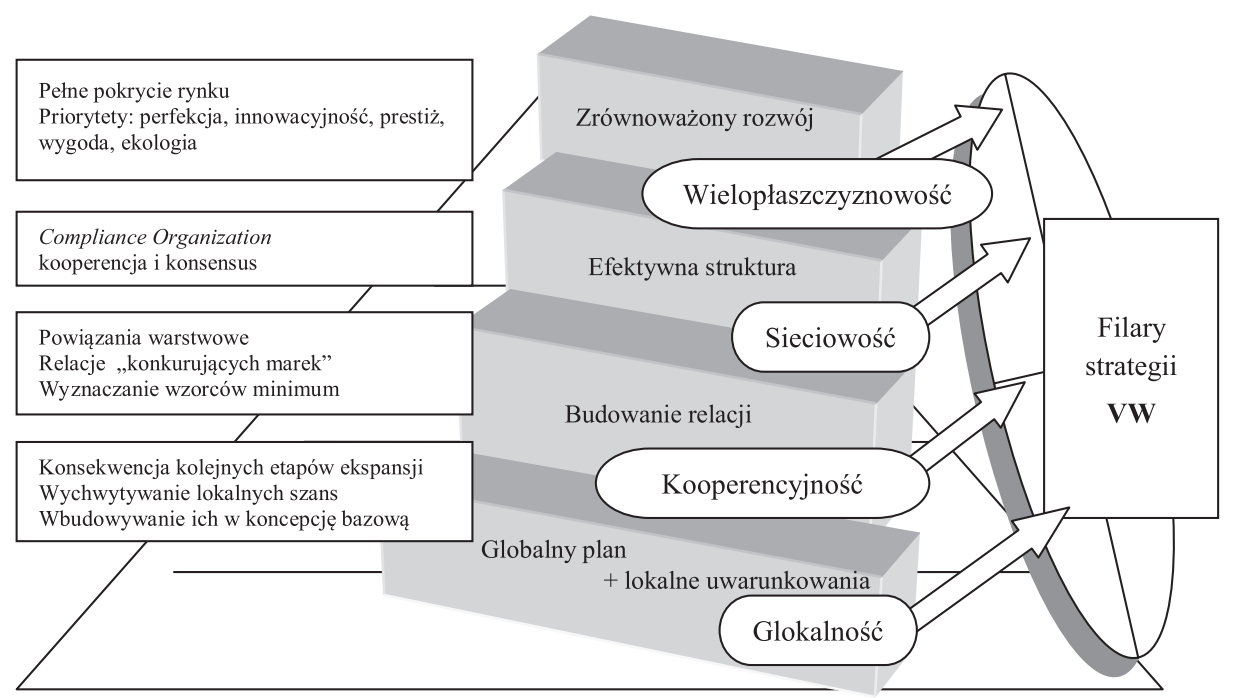

Ź r ó d ł o: opracowanie własne na podstawie: Annual Report Volkswagen 2010, Strategy 2018. 
Analiza filarów rozwoju Toyoty, Forda i VW wykazała, że choć expressis verbis zapisy wytycznych strategii nie są identyczne, $\mathrm{w}$ istocie mówią o tym samym. Glokalność to efekt połączenia standardu globalnego, wymogów dla wszystkich marek sieci VW, stosowania pewnych identycznych elementów i ich „lokalnego" dostosowywania, odzwierciedlającego specyficzne dla konkretnej marki (nie regionu) wymogi ${ }^{18}$. Dla Forda glokalność to standard plus lokalność, ale w tym przypadku oznaczająca modyfikacje pod specyfiki regionów. Dla Toyoty ten filar oznacza standardowe procesy, wzbogacane na bazie lokalnych kompetencji. Spójność wszystkich interpretacji opiera się na uznaniu jednolitej definicji istoty glokalności jako lokalnej wartości dodanej do stale rosnącego globalnego standardu. Podobna interpretacja dotyczy sieciowości. Dla Toyoty to społeczność obejmująca producentów, dealerów, klientów, którzy budują powiązania służące poprawie efektywności systemu. W Fordzie to sieć koordynująca globalnie rozproszone aktywności, dzięki odpowiedniemu podziałowi ryzyka i odpowiedzialności. Dla VW to pajęczyna setek podmiotów sieci, z punktami węzłowymi w postaci głównych marek. Z uwagi na szeroki portfel marek pokrywających wszystkie obszary branży motoryzacyjnej kooperencyjność VW koncentruje się na relacjach wewnątrz sieci. W Toyocie to współpraca z najsilniejszymi konkurentami na poziomie powiązań kooperencyjnych na półotwartej granicy sieci. W Fordzie jej istota tkwi w podziale aktywności. Bezwzględne konkurowanie tam, gdzie przewaga pozwala na osiągniecie pozycji lidera. Kooperowanie jako benchmarking, uczenie się, dzielnie się wiedzą z konkurentami. Wielopłaszczyznowość to ze swej natury element strategii polegający na godzeniu różnorodności, który u każdego KTN-orchestrators oznacza równoważenie oczekiwań wielu interesariuszy sieci, z tym, że z uwagi na odmienne kultury macierzyste procesy te bazują na nieco innej piramidzie wartości.

Analizując filary strategii Toyoty, Forda i VW, stwierdzono, że uzyskały one status KTN-orchestrators, budując rozwój na wartościach adekwatnych do wyzwań XXI w. Należy zauważyć, że zbieżność filarów strategii stanowiących ich fundamenty rozwoju jest obecnie znacznie wyraźniejsza niż wcześniej wdrażanych przez nie koncepcji konkurencyjności. Analiza etapów modeli integracji biznesowej wskazuje, że ich rozwój przebiegał w innych warunkach, dlatego ich posunięcia taktyczne i operacyjne nie były identyczne. Korporacje te wykorzystywały inne drogi internacjonalizacji, jednak uwzględniały te same wymogi stawiane przez ewoluującą gospodarkę światową, dlatego w efekcie pokonywały kolejne stopnie integracji i doszły do etapu GSB. Wchodząc na poziom KTN-orchestratora GSB,

18 „Lokalność” - w tym przypadku nie w znaczeniu geograficznym, ale miejsca danej oferty w systemie (luksusowa, masowa, sportowa etc.). 
musiały przejść swoiste przeobrażanie, oznaczające wymóg łączenia partykularnych interesów pomnażania aktywów z wymogami zrównoważonego rozwoju, kreatywności, innowacyjności i budowania wartości społeczno-ekonomicznych. GSB stanowi model struktury docelowej, czyli osiagnięcie tej fazy było efektem dojrzałości wypracowanej strategii - dlatego ostatecznie priorytety rozwoju są adekwatne dla XXI w. i można je zapiać w postaci spójnych filarów.

\section{Podsumowanie}

W XXI w. KTN stanęły nie tylko wobec wyzwania rozdzielenia własności od zarządzania, stosowania modelu regulacyjnego, ale przede wszystkim sprostania wymogom zarządzania zrównoważonego. Oznacza to stałe kreowanie wartości dodanej do wymogów ewoluującego otoczenia zewnętrznego i wewnętrznego. W artykule starano się wykazać, że postawa KTN wobec tych wyzwań to dostosowania strategii w rytm zmian w gospodarce światowej. W efekcie pojawily się GSB, a najpotężniejsze KTN zyskały status KTN-orchestrators, które, chcąc sprostać nowym wyzwaniom, musiały wpracować adekwatne filary strategii.

Celem artykułu było wskazanie kierunku zmian w KTN w efekcie dostosowań do wyzwań XXI w. Badania potwierdziły, że zmieniające się wymogi wymusiły na KTN dostosowania strategii i przebudowę modeli organizacyjno-zarządczych. KTN ewoluowały, budując wielopoziomowe GSB - wypracowały pewien uniwersalny schemat tych zmian. Najpotężniejsze KTN zdolne łączyć idee orkiestracji i kooperencji uzyskały status KTN-orchestrators GSB. Wykorzystując metodologię teorii ugruntowanej, ustalono, że ich strategie bazują obecnie na spójnych filarach: sieciowości, kooperencji, glokalności, wielopłaszczyznowości.

Konkluzja: ewolucja KTN w kierunku GSB stanowi realizację dostosowań do wyzwań XXI w. Oznacza przejście od modelu strategicznej przedsiębiorczości korporacyjnej (tradycyjna KTN), opartego na sile aktywów własnych i ich zakresie umiędzynarodowienia do modelu zintegrowanego zarządzania zrównoważonego, czyli idei organizacji wielowarstwowej o wewnętrznie zróżnicowanych systemach organizacyjno-zarządczych, orkiestrowanej z zastosowaniem modelu regulacyjnego (KTN-orchestrator GSB). Z uwagi na złożoność powstałej organizacji sieciowej do badań nad KTN-orchestrators GSB godne rekomendowania wydaje się wykorzystanie podejścia interdyscyplinarnego, w tym analiz sieciowych, koncepcji integracji, gospodarki opartej na wiedzy, kreacji wartości społecznie-użytecznych. Pozwoli to na pełniejsze opisanie specyfiki reakcji KTN na wyzwania XXI w. 


\section{Bibliografia}

\section{Opracowania}

Annual Report Ford Motor Company, 2014, http://corporate.ford.com/annual-reports-2014/pdf; stan na 29.09.2015 r.

Annual Report Ford Motor Company, 2010, ONE Ford. One Team. One Plan. One Goal.

Annual Report Toyota, Toyota's DNA Will Endure for the Next 100 Years, 2014, http://www.toyota-global.com/investorslibrary/annual/pdf; stan na 25.09.2015 r.

Annual Report Volkswagen 2010, Strategy 2018, http://annualreport.volkswagenag. com/managementreport/strategy2018.html; stan na 29.09.2015 r.

Blomstermo Anders, Sharma Deo D., Learning in the Internationalization Process of Firm, Edward Elgar Publishing, Cheltenham Northampton, Massachusetts 2003.

Brown Terrence, Davidsson Per, Wiklund Johan, An Operationalization of Stevenson's Conceptualization of Entrepreneurship as Opportunity - based Firm Behavior, Strategic Management Journal 2001/22.

Cygler Joanna, Kooperencja przedsiębiorstw, Wydawnictwo SGH, Warszawa 2009.

De Wit Bob, Meyer Ron, Synteza strategii, PWE, Warszawa 2007.

Dunning John H., The Eclectic (OLI) Paradigm of International Production: Past, Present and Future, International Journal of the Economics of Business 2001/8/2.

Fung Victor K., Fung William K., Wind Yoram (Jeery), Konkurowanie w płaskim świecie, Wydawnictwa Akademickie i Profesjonalne, Warszawa 2008.

Gorynia Marian, Jankowska Barbara, Teorie internacjonalizacji, Gospodarka Narodowa 2007/10.

Gorynia Marian, Jankowska Barbara, Klastry a międzynarodowa konkurencyjność i internacjonalizacja przedsiębiorstwa, Difin, Warszawa 2008.

Götz Marta, Jankowska Barbara, Zastosowanie metodologii teorii ugruntowanej (GTM) w badaniu koopetycji w klastrach, Problemy Zarządzania 2014/12/3 (47).

Gereffi Gary, Humphrey John, Sturgeon Timothy, The governance of global value chains, Review of International Political Economy 2005/12/1.

Hagel John, Brown John S., The Only Sustainable Edge: Why Business Strategy Depends on Productive Friction and Dynamic Specialization, Harvard Business School Press, Boston 2005.

Klimas Patrycja, Structural face of competition, cooperation and coopetition inside business networks, Argumenta Oeconomica 2015/1/34.

Liker Jeffrey K., Droga Toyoty. 14 zasad zarządzania wiodącej firmy produkcyjnej świata, MT Biznes, Warszawa 2005.

Pakulska Teresa, Poniatowska-Jach Małgorzata, Non-Equity Modes as international business strategy. From Ownership to Control, Lambert Academic Publishing, Saarbrücken 2015.

Pedersen Torben, Venzin Markus, Devinney Timothy M., Tihanyi Laszlo (red.), Orchestration of the Global Network Organization, Emerald Group Publishing, Howard House, Wagon Lane, Bingley, Advances in International Management 2014/27.

Radło Mariusz-Jan, Międzynarodowa konkurencyjność gospodarki, w: Wojciech Bieńkowski i in., Czynniki i miary międzynarodowej konkurencyjności gospodarek w kontekście globalizacji - wstępne wyniki badań, Prace i Materiały nr 284, IGŚ SGH, Warszawa 2008. 
Rosińska-Bukowska Magdalena, Najpotężniejsze korporacje współczesnego świata, Wydawnictwo WSSM, Łódź 2011.

Rosińska-Bukowska Magdalena, Rozwój globalnych sieci biznesowych jako strategia konkurencyjna korporacji transnarodowych, Wydawnictwo Uniwersytetu Łódzkiego, Łódź 2012.

Sulejewicz Aleksander, Partnerstwo strategiczne: modelowanie wspótpracy przedsiębiorstw, Monografie i Opracowania 1997/427, Wydawnictwo SGH, Warszawa.

Thomson Grahame, Frances Jennifer, Levacic Rosalind, Mitchell Jeremy, Markets, Hierarchies and Networks: The Co-ordination of Social Life, Sage Publications, London 1991.

Wheelen Thomas L., Hunger David J., Concepts in Strategic Management and Business Policy, Pearson Prentice Hall, New Jersey 2006.

Wiedersheim-Paul Finn, Olson Hilary C., Welch Lawrence S., Pre-Export Activity: The First Step in Internationalization, Journal of International Business Studies 1978/9 (1).

World Investement Reports (1991-2015), www.unctad.org; stan na 25.09.2015 r.

\section{Magdalena ROSIŃSKA-BUKOWSKA}

\section{TRANSNATIONAL CORPORATIONS IN CONSIDERATION OF CHALLENGES 21ST CENTURY}

\section{( $S$ u m m a ry)}

The aim of the study is an attempt to indicate how transnational corporations have changed as a result of waves of globalization. The author makes effort to demonstrate that pillars of development models TNC-orchestrators is their response to the challenges of 21 st century.

The article consists of three parts. The first one presents the evolution of transnational corporations (TNCs), seen as the consequence of changes in the economy. The efforts were made to indicate how the consecutive stages of globalization have determined the changes in corporations' strategies. TNCs manifestation of the changes at that stage corporate globalization is the development of Global Business Networks (GBN). It was noted that they are a result of implementing the concept of integration as a method of improving the competitiveness of the participating actors - business integration model. The second part of the study is discussion on the substance of the changes in management models of transnational corporations which are to meet new challenges. The attention was drawn to a new type of entities - TNC-orchestrators, which because of its nature (pillars of development models), should be treated differently to a traditional business. In the last part of article the author presented pillars of development models TNC-orchestrators GBN as a case study for the automotive sector (Toyota, Ford, VW).

Keywords: transnational corporations; TNC; orchestration; globalization; business networks 